\title{
Me first, then the environment: young Millennials as green consumers
}

Iman Naderi

Fairfield University, inaderi@fairfield.edu

Eric Van Steenburg

Follow this and additional works at: https://digitalcommons.fairfield.edu/business-facultypubs Copyright 2018 Emerald Publishing Limited

The author post-print has been archived here with permission from the copyright holder.

\section{Peer Reviewed}

\section{Repository Citation}

Naderi, Iman and Van Steenburg, Eric, "Me first, then the environment: young Millennials as green consumers" (2018). Business Faculty Publications. 211.

https://digitalcommons.fairfield.edu/business-facultypubs/211

\section{Published Citation}

Iman Naderi, Eric Van Steenburg, (2018) "Me first, then the environment: young Millennials as green consumers", Young Consumers, https://doi.org/10.1108/YC-08-2017-00722.

This item has been accepted for inclusion in DigitalCommons@Fairfield by an authorized administrator of DigitalCommons@Fairfield. It is brought to you by DigitalCommons@Fairfield with permission from the rightsholder(s) and is protected by copyright and/or related rights. You are free to use this item in any way that is permitted by the copyright and related rights legislation that applies to your use. For other uses, you need to obtain permission from the rights-holder(s) directly, unless additional rights are indicated by a Creative Commons license in the record and/or on the work itself. For more information, please contact digitalcommons@fairfield.edu. 


\title{
Me First, Then the Environment: Young Millennials as Green Consumers
}

\author{
Published in Young Consumers
}

Link: https://www.emeraldinsight.com/doi/abs/10.1108/YC-08-2017-00722

\author{
Iman Naderi, Ph.D. \\ (Corresponding Author) \\ Assistant Professor of Marketing \\ Charles F. Dolan School of Business, Fairfield University \\ inaderi@fairfield.edu \\ Eric Van Steenburg, Ph.D. \\ Assistant Professor of Marketing \\ Jake Jabs College of Business \& Entrepreneurship, Montana State University \\ eric.vansteenburg@montana.edu
}

Iman Naderi is assistant professor of marketing at Charles F. Dolan School of Business, Fairfield University. His main area of research is social psychology of consumer behavior with his current focus on sustainable consumption, green consumers, narcissistic consumers, and social influence. His work has appeared in the Journal of Macromarketing, Journal of Consumer Marketing, Journal of Applied Social Psychology, and International Journal of Consumer Studies, among others.

Eric Van Steenburg is assistant professor of marketing at Jake Jabs College of Business \& Entrepreneurship, Montana State University. His research interests center on cause marketing. Before embarking on a career in academia, Eric spent 20 years in corporate, agency and nonprofit environments leading strategic planning and integrated marketing communications to support business objectives and brands. His work has appeared in International Journal of Advertising, Journal of Consumer Behaviour, Journal of Product \& Brand Management, and Industrial Marketing Management, among others. 


\begin{abstract}
Purpose: This research aims to shed greater light on millennials' green behavior by examining four psychographic variables (selfless altruism, frugality, risk aversion, and time orientation) that may be relevant to millennials' motives to engage in environmental activities.
\end{abstract}

Design/methodology/approach: The data were collected from a sample of younger millennials ( $\mathrm{n}=276$, ages 18 to 30 ) using a self-administered questionnaire. The data were then analyzed using structural equation modeling (SEM) technique.

Findings: Overall, the results of the study reveal that rational and self-oriented rather than emotional and others-oriented motives lead millennials to act pro-environmentally.

Practical implications: The findings of this study have implications for environmental advocates, policy makers, and green marketers. For instance, the findings suggest that environmental regulators and law makers should continue their efforts to provide economic incentives to encourage pro-environmental purchases among millennials. Additionally, marketers of green products may pursue self-directed targeting strategies in promoting green products among millennials.

Originality/value: Millennials grasp the environmental consequences of their actions and have the education, motivation and social awareness to participate in the green movement. However, they have not truly begun to fully integrate their beliefs and actions. The present study is an initial attempt to address this issue by investigating various psychological factors that are relevant to the millennials' core behavioral motives.

\title{
Keywords
}

Millennials; Green Consumption; Pro-environmental Behavior; Sustainable Consumption; Selfinterest 


\section{Me First, Then the Environment: Young Millennials as Green Consumers}

\section{Introduction}

During the past three decades there has been massive growth in environmental awareness and concerns, especially in more developed economies such as the United States and Western European countries (Chen and Chai 2010; Franzen 2003; Jain and Kaur 2004; Wray-Lake et al. 2010). Over this period, the market for environmentally friendly products (a.k.a. green products) has begun to extend to nearly every facet of the market. At local stores, consumers now have the ability to purchase household cleaning products, several types of food, and even bottles of water that have, in some way, integrated the green scheme of marketing into products. Further, consumers' environmentally friendly behavior could go well beyond purchasing green products and be extended to various domains such as car sharing, water and energy conservation, and reuse, recycling or responsible disposal of the products (e.g., Bekin, Carrigan, and Szmigin 2007; Seitz and Peattie 2004; Frame and Newton 2007; McKenzie-Mohr 2000).

In the extant marketing and environmental literature, research efforts have sought to identify, analyze, and understand "green consumers" (Diamantopoulos et al. 2003; Jain and Kaur 2006; Moisander 2007; Peattie 2001; Straughan and Roberts 1999), and green consumption is naturally regarded as a process that is strongly influenced by consumer values, norms, and habits (Peattie 2010). Specifically, a more recent and growing body of research is focused on young consumers, investigating how environmental behaviors and attitudes are developed and shaped (Casaló and Escario 2016; Otto and Kaiser 2014) and examining the factors that may encourage or hinder pro-environmental behaviors among this segment of consumers (Fischer, Böhme, and Geiger 2017; Lee 2008; Lee et al. 2016; Muralidharan and Xue 2016). The present study aims to 
contribute to the latter group by investigating how millennials' psychological characteristics may influence their intentions to engage in environmental actions.

Characterized as the largest generation of consumers, millennials (a.k.a. Generation Y) are formally defined as those who were born between 1982 and 2000 (U.S. Census Bureau 2015), reaching young adulthood in the early 21 st century. While some research regarding this group of consumers shows that being environmentally friendly is key to attracting their interest, and they seek brands they regard as having a positive effect on the environment (Henrichs 2008; Rosenburg 2015), other studies refute such generalizations and suggest that millennials are more attitudinally green than behaviorally green (Diamantopoulos et al. 2003; Grønhøj and Thøgersen 2009; Johnson et al. 2004; Uyeki and Holland 2000). Still others show a divide in millennials' green consumption habits based on variables such as ecological knowledge (Kanchanapibul et al. 2014), lifestyle (Jang et al. 2011), social influence (Lee 2008; Muralidharan and Xue 2016), transfer of environmental attitudes from parents to children (Casaló and Escario 2016; Meeusen 2014), and even gender (Anvar and Venter 2014; Lappänen et al. 2012). Millennial consumers, similar to their older counterparts, value accessibility, affordability, and quality, while green products are often associated with inconvenience, high costs, and lower performance (e.g., Chen and Chai 2010; Mainieri et al. 1997; Newman, Gorlin, and Dhar 2014; Ottman, Stafford, and Hartman 2006). Is it possible, then, that millennial consumer may see green products as an inconvenience despite their positive attitudes toward the environment?

This research aims to shed greater light on millennials' green behavior and provide a theoretical explanation for these conflicting preconceptions. In doing so, it focuses on how individual psychographic characteristics may affect consumption behavior among this generation of consumers. Research into millennials identified three smaller cohorts within the generation that 
behave differently in terms of consumption. These socio-demographic categories include single college students, single young professionals, and married young professionals (Gurău 2012). It is the first cohort that is the population of interest for the present research.

Further, in the environmental literature, an extensive body of work has investigated characteristics of green consumers that differentiate them from other consumers. Particularly, several early studies in this domain strived to profile green consumers in order to develop meaningful market segmentations using various criteria (Kilbourne and Beckmann 1998; Peattie 2010). Variables examined typically included age, gender, number of children, education, and socioeconomic status (e.g., Casimir and Dutilh 2003; Laroche, Bergeron, and Barbaro-Forleo 2001; Olli, Grendstad, and Wollebark 2001; Roberts 1996; Straughan and Roberts 1999; Shrum et al. 1995). However, in a comprehensive review of this research stream, Diamantopoulos et al. (2003) concluded that, while sociodemographic variables cannot be ignored, they offer limited value when trying to profile green consumers or understand green consumption behavior. In addition, previous research (Schwepker and Cornwell 1991; Shrum et al. 1995) shows that demographic variables typically have less explanatory power compared to psychographic variables. Therefore, the present investigation focuses on four major psychographic characteristics of this generation (i.e., altruism, frugality, risk aversion, and time orientation) that may be relevant to their motives to engage in environmental consumption.

In doing so, the research makes four key contributions: (1) it challenges the presumption that millennials are environmentalist in nature; (2) it helps identify the reasons behind millennials' pro-environmental consumption behaviors by challenging the empathy-altruism hypothesis; (3) it confirms the motives that are more important in predicting millennials' commitment to act as green 
consumers; and (4) it provides a starting point for developing strategies that marketers of green brands can use to reach this economically powerful generation.

\section{Are Millennials Really Green?}

As millennials, the largest generation in the United States at more than 83 million (U.S. Census Bureau 2015), reach their prime working and spending years, their impact on the economy will be extensive. With an estimated $\$ 200$ billion in annual buying power (Schawbel 2015), millennials have grown up during a time of technological change, globalization and economic disruption, giving them a different set of behaviors and experiences than their parents.

Despite the fact that millennials have grown up in one of the most difficult economic climates, a global study (Nielsen 2015) found that this group continues to be most willing to pay extra for sustainable offerings. More precisely, almost three-out-of-four millennial respondents were willing to pay more for brands committed to a positive social and environmental impact, compared to only $51 \%$ of baby boomers (ages 50-64) willing to pay extra. In addition, for those willing to spend more, personal values outweigh personal benefits, such as cost or convenience. Millennials are also supportive of stricter environmental laws, more likely to attribute global warming to human activity, and likely to favor environmentally friendly policies such as green energy development and economic incentives for sustainability (Pew Research Center 2011).

Despite this, it is still debatable as to whether or not millennials are committed to going green. In a U.S. nationwide survey, although $69 \%$ of millennials expressed genuine interest in the environment, they appear to have a lack of personal involvement in green-related activities (Diamantopoulos et al. 2003). For instance, only 33\% of American millennials always recycle, compared with $51 \%$ of American adults. In addition, millennials fell behind the general population on other environmental issues, such as drinking water from reusable containers, minimizing water 
usage during daily tasks, and unplugging electronics or turning off power strips (Head 2013). Further, millennials do not select the environment over their personal comfort or convenience, nor do they consider themselves to be more personally responsible to change their behavior to positively impact the environment (Grønhøj and Thøgersen 2009).

In sum, the strength of pro-environmental attitudes and behaviors among millennials depends on individual and personal characteristics. In fact, green consumption behavior may be influenced by general characteristics that lead to different motives to engage in green behavior. The following section examines four important characteristics of this generation: (1) selfless altruism; (2) consumer frugality; (3) future orientation; and (4) risk averseness.

\section{Conceptual Development and Hypotheses}

\section{Selfless Altruism}

A motivational state with the goal of increasing another's welfare (Batson 1991), selfless altruism has been argued to be a quality that millennials are lacking (Twenge and Campbell 2009; Twenge and Foster 2010). This generation has been characterized as selfish, individualist, entitled, and even narcissist, leading Twenge (2006) to label it Generation Me. In addition, extant research in social and clinical psychology (e.g., Cramer 2011; Horton and Tritch 2014; Horton, Bleau, and Drwecki 2006) has shown that adolescents' other- (vs. self-) oriented characteristics and behaviors could be shaped by parenting styles and practices (e.g., warmth, psychological control, monitoring, support, overvaluation).

The first explanation for why some people engage in pro-environmental activities is environmental concern (Bamberg 2003; Schwepker and Cornwell 1991). People are normally motivated to engage in pro-environmental behavior because they inherently care about the environment and its human occupants. Therefore, altruism may be a strong motive for some 
individuals, leading them to act environmentally friendly. In fact, de Groot and Steg (2009) suggest that altruistic considerations provide the most stable basis for pro-environmental behavior, and thus it is important to strengthen altruism to promote such behavior. In addition, Clark, Kotchen, and Moore's (2003) study shows that altruism is an internal variable that influences green behavior. Other studies (e.g., Chan 2001; Li 1997) have demonstrated the significant effect of an individual's collectivist orientation (group altruism) on his or her pro-environmental actions.

While the findings of the aforementioned studies generally support the existence of a positive relationship between individuals' selfless altruism and their willingness to engage in green behavior, each employed research samples that included participants from various generations. In addition, Kollmuss and Agyeman (2002) argued that people who satisfy their personal needs are more likely to act ecologically because they have more resources (time, money, energy) to care about bigger, less personal, social and pro-environmental issues. Comparatively, Geller (1995) hypothesized that in order to act pro-environmentally, individuals must be able to think beyond the satisfaction of their own immediate needs and be concerned about the well-being of others and their community at large. Geller (1995) further suggested that this state of "actively caring" can only occur if personality factors related to self-affirmation (i.e., self-esteem, belonging, and personal control) have been satisfied. However, it is worth noting that millennials may lack some of these qualities as they are still in their early stages of adulthood and independence. Therefore, it is quite possible that the findings of previous research are not extendable to this generation. The first hypothesis examines the effect of selfless altruism on green consumption behavior in millennials:

H1: Millennials who are higher in selfless altruism tend to engage in green consumption behaviors more frequently. 


\section{Consumer Frugality}

From a rational economic perspective, consumer frugality could also be important in motivating consumers to buy green products (Peattie 2001; Schaefer and Crane 2005; Stern 1999). For example, the money saving associated with driving hybrid cars or using LED light bulbs may encourage value-conscious consumers to purchase these products. In fact, some studies claim that the increased enthusiasm for green products is partly due to consumers' perception of green as money saving. For example, nearly $60 \%$ of American consumers practice "green" behaviors to save money rather than support the environment, and this sentiment is higher among millennials (Rosenburg 2015).

Consumer frugality, defined as "careful use of resources and avoidance of waste" (DeYoung 1986, p. 285), is investigated in this study because it encompasses the careful use of both financial and physical resources. Prior to adulthood, saving and spending patterns could be influenced by family factors. For instance, Pritchard, Myers, and Cassidy (1989) found that adolescent savers were from families who saved and planned their use of money whereas discretionary spenders were mostly from families with higher income and socioeconomic status. It is expected that consumers who are careful in how they use their financial and physical resources will engage in pro-environmental behaviors more frequently. In addition, less consumption, only buying needed things, using things until they are worn out, and not wasting things are all forms of behaviors that not only save money, but also are good for the planet, and thus can be labeled proenvironmental.

Frugality and economic motives are particularly critical in millennials' decision making as their financial resources are limited. In fact, numerous millennials came of age during the global economic recession of the last decade, which was also a time when hybrid cars and energy-saving 
light bulbs helped link economic pragmatism and environmental sustainability in the consumer psyche (Rosenburg 2015). As a result, millennials' purchase habits are shaped both by strong ecofriendly ideals combined with an economizing mindset. Therefore, it is hypothesized that:

H2: Millennials who are more frugal tend to engage in green consumption behaviors more frequently.

\section{Future Orientation}

Environmental concerns and economic considerations, while important, are not the only motivating factors relevant to making decision about pro-environmental consumption among millennials. Temporal considerations (e.g., time orientation) could also be equally important. Until recently, however, they have received relatively little attention in the environmental literature. Time orientation refers to the direction (i.e., past, present, or future) that most commonly motivates a person's behavior and thinking (Zimbardo and Boyd 1999). Based on this framework, future orientation is broadly defined as the extent to which an individual thinks about the future, anticipates future consequences, and plans ahead before acting (Steinberg et al. 2009). Across development, future orientation is particularly important during periods of major changes, for example during the transition from adolescence to adulthood, when youth must make choices about social groups, academic paths, as well as risky behaviors (McCabe and Barnett 2000).

Environmental issues are generally related to the future. That is, pro-environmental actions and green behaviors are expected to have long-term, rather than short-term, effects. On the other hand, previous studies indicate that the importance attached to future outcomes is a function of both situational (Stern 1976) and personal factors (Zimbardo and Boyd 1999). More specifically, Strathman et al. (1994) found that individuals perceive the immediate versus delayed consequences of their actions differently. And people with higher scores on consideration of future consequences 
scale (Strathman et al. 1994) are more easily persuaded by the long-term benefits of environmental interventions. This suggests that future-oriented individuals are more likely to engage in proenvironmental behaviors.

The argument for millennials, however, is slightly more complicated. On one hand, research shows that millennials are more likely to live in the moment and not have as much concern with the long-term consequences of their choices (Norum 2008). In fact, millennials display a lack of patience, often make decisions based on how quickly the choice can be made rather than careful evaluation, and seek instant gratification (Aruna and Santhi 2015). On the other hand, research also suggests that millennials are future-oriented; younger adults generally tend to be more future oriented than both older adults (60-86 years old; Webster and Ma 2013) and younger adolescents (10-16 years old; Steinberg et al. 2009). As a result, future-oriented millennials would accept delays of immediate gratification to achieve longer-term better goals, would be willing to invest effort and resources in current activities that have a distant payoff, and would endure unpleasant current situations that have the potential for positive future outcomes (Zimbardo and Boyd 1999). Consequently, future orientation could be an important predictor of green consumption behavior for millennials because they have to live longer with the consequences of today's environmental decisions. Therefore, this study examines future time orientation, which is related to one's general attitude toward the future rather than a specific outcome orientation. It is hypothesized that:

H3: Millennials who are more future-oriented tend to engage in green consumption behaviors more frequently.

\section{Risk Averseness}

As they enter the workforce and consider their futures, millennials have become a riskaverse generation (Henry 2017). This was not always the case, however, as just prior to The Great 
Recession that began in 2009, research showed millennials were less brand loyal and less risk averse than generation X (Reisenwitz and Iyer 2009). But now, Winograd and Hais (2014) found $52 \%$ of millennials have a majority of their money in cash, whereas other generations have $23 \%$ in cash, suggesting that young adults are reluctant to put money into the stock market. From a developmental point of view, millennials have seen parents lose their jobs, homes, and equity after two severe economic downturns in the past 15 years. Therefore, this generation is in a perpetual state of considering safety and security, leading to risk-averse behaviors. In fact, a recent study by Larson, Eastman, and Bock (2016) found a strong connection between millennials' financial risk taking and the climate of risk brought on by the Great Recession that began in 2008.

Generally, the concept of environmental risk (i.e., the risk attached to physical and social environmental factors) is considered a strong predictor of behavior (Rutter et al. 2001). Particularly, previous research shows that the more individuals perceive potential risks in their environment, the more they are motivated to perform green behaviors (e.g., Seguin et al. 1999). However, as Meijinders et al. (2001) argued, understanding the link between environmental phenomena (e.g., climate changes) and individual behavior (e.g., driving a SUV everyday) is difficult in the context of large-scale environmental risks, such as the greenhouse effect. Therefore, the basic challenge is "to convince people that they are at risk, and that they can and should take action to minimize this risk" (Meijinders et al. 2001, p. 755).

On the other hand, individuals differ in their risk attitudes (i.e., risk-averse, risk-neutral, or risk-taking). Consequently, risk-averse millennials are expected to have higher motivation to demonstrate pro-environmental consumption behaviors, which in turn, they hope, will reduce the risk of living in a deteriorating environment in the future. Based on this, it is hypothesized that: 
H4: Millennials who are risk-averse tend to engage in green consumption behaviors more frequently.

\section{Method}

\section{Sample}

A total of 285 students from a large U.S. public university participated in this study in exchange for course extra credit. Self-administered questionnaires were used and nine questionnaires were excluded due to incompleteness, resulting in a final sample of 276 participants (52.9\% males). Participants ranged in age from 18 to 30 years $(M=24.44, \mathrm{SD}=5.72)$, qualifying them as millennials (Gurău 2012).

\section{Measurements}

Selfless altruism was measured on six semantic differential items $(\alpha=.820)$, ranging from 1 (never) to 7 (very often). The items were adapted from the Self-Report Altruism Scale (SRAS; Rushton et al. 1981) and contextualized for the time and sample of the study. This scale was used because it measures altruism as an individual's inherent tendency to engage in altruistic actions rather than his or her general attitudes and beliefs with regard to altruism and social responsibility. Sample items include: "I have done volunteer work for a charity" and "I have let someone borrow an item of some value to me." Frugality (Lastovicka et al. 1999) was measured on seven items ( $\alpha$ $=.842$ ), ranging from 1 (strongly disagree) to 7 (strongly agree). Sample items include: "Making better use of my personal resources makes me feel good" and "I discipline myself to get the most from my money." Future orientation was also measured on seven items $(\alpha=.846)$, ranging from 1 (strongly disagree) to 7 (strongly agree), which were adapted from the future time orientation dimension of the Stanford Time Perspective Inventory (Zimbardo and Boyd 1999). Sample items include: "I make lists of things to do", "I am able to resist temptations when I know that there is 
work to be done", and "When I want to achieve something, I set goals and consider specific means for reaching those goals." Risk averseness was measured on the four-item risk averseness scale ( $\alpha$ $=.672$; Burton et al. 1998). The statements, rated on scales from 1 (strongly disagree) to 7 (strongly agree), generally measure the degree to which a consumer avoids taking risks in life. Sample items include: "I have no desire to take unnecessary chances on thing" and "Compared to most people I know, I like to gamble on things" (reveres-coded). Finally, covering a wide range of proenvironmental consumption behaviors (e.g., buying products that are made from recycled materials, can be recycled, are low in pollutants, or are sold by ecologically responsible companies, buying fruits and vegetables grown without pesticides, and buying high efficiency light bulbs), green consumption behavior was measured on 11 items $(\alpha=.924)$ adopted from the scales developed by Roberts (1996) and Stern et al. (1999). Sample items include: "I make every effort to buy plastic products made from recycled materials", "I try only to buy products that can be recycled", and "I do not buy products from ecologically irresponsible companies." The items were rated from 1 (never true) to 7 (always true).

\section{Analysis and Results}

Before testing the model, confirmatory factor analysis was conducted (see Table 1), indicating that all the factor loadings were significant at .01 (standardized lambdas range from .49 to .83 ). Composite reliabilities range from .676 to .926 , indicating acceptable levels of reliability (Fornell and Larcker 1981). Discriminant validity was assessed by calculating the shared variance between all possible pairs of constructs $\left(\Phi^{2}\right)$, and verifying that for each pair the highest shared variance (HSV) is lower than the average variance extracted (AVE) of each individual respective construct. All pairs pass Fornell and Larcker's (1981) test indicating discriminant validity among the constructs. 


\section{INSERT TABLE 1 ABOUT HERE}

\section{INSERT TABLE 2 ABOUT HERE}

Structural equation modeling was used to test the hypotheses. As reported in Table 2, the results for absolute, incremental, and parsimonious fit indices, as well as other commonly used fit indices demonstrate the proposed model is well-fitted with the data (Chi-square $=1049.40, \chi^{2} / d f=$ $1.91, \mathrm{GFI}=.82, \mathrm{CFI}=.95, \mathrm{IFI}=.95, \mathrm{NFI}=.91, \mathrm{RMSEA}=.057, \mathrm{SRMR}=.063)$. The analysis of the structural equation model (see Figure 1) shows that the link between selfless altruism and green behavior is not significant $(\gamma=-.08, t=-1.00)$; that is, selfless altruism is not a significant predictor of green consumption behaviors for millennials. Therefore, H1 is not supported. The findings also reveal that the path from frugality to green behavior is positive and significant $(\gamma=$ $.34, t=4.11)$. Therefore, supporting $\mathrm{H} 2$, frugality in millennials is a significant antecedent of their intentions to engage in green consumption behaviors. In addition, the hypothesized relationship between future orientation and green behavior is supported as this path is positive and significant $(\gamma=.18, t=2.07)$. Hence, future orientation characteristics of millennials significantly influence their pro-environmental consumption behaviors, supporting H3. Finally, the results show that no significant relationship exists between risk averseness and green behavior $(\gamma=-.07, t=-.95)$. Therefore, millennials' attitudes toward risk (here, risk avoidance) does not play a significant role in their intentions (or lack thereof) to engage in green consumption practices, indicating a lack of support for $\mathrm{H} 4$.

\section{INSERT FIGURE 1 ABOUT HERE}

\section{General Discussion}

A variety of pro-environmental purchase and consumption behaviors are investigated in this study. This work shows that, as predicted, frugality, which is a rational and self-oriented 
motive, is a significant driver of green consumption among college age millennials. As discussed, millennials' resources, both financial and physical, are limited as most of them are in their early stages of financial independence. In addition, they have been raised during two of the worst economic recessions in the history (2001 and 2008). As a result, it is hardly surprising to see that millennials have extended such defensive, saving-oriented mindsets in protecting their own resources to the environment in which they live.

This investigation also reveals that, as expected, having a future-oriented mindset in millennials is a significant predictor of green consumption. Environmental impacts, whether conserving or harmful, are more salient in long-term. This idea explains why future-orientation generally plays a significant role in the context of environmental conservation. In the case of millennials, however, there are conflicting views about whether or not they truly are futureoriented. Such wide disagreements could explain why some studies have described millennials as an environmentalist cohort of consumers (Henrichs 2008; Rosenburg 2015) while others have questioned this generalization (Diamantopoulos et al. 2003; Grønhøj and Thøgersen 2009; Johnson et al. 2004).

Further, while millennials are described as a risk-averse generation, the results here show this characterization does not translate into pro-environmental actions. This could be because in the context of environmental conservation, risks that may directly impact an individual are generally shorter in scope compared to those that may impact the environment. Therefore, study participants did not perceive their green consumption behaviors as endeavors that reduce the potential risk on themselves. Future research, however, needs to examine this possibility.

The final, and perhaps most interesting, finding of this study is the lack of a significant relationship between selfless altruism and pro-environmental consumption. Altruism, as an 
indicator of helping and caring for others, does not lead millennials to engage in environmentally friendly consumption. This finding questions the generalizability of the findings in previous studies that show altruism is a predictor of pro-environmental behavior in general samples (e.g., Clark, Kotchen, and Moore 2003; de Groot and Steg 2009), but could support the results of WrayLake et al. (2010) who saw a trend by young people to place the responsibility for environmental conservation on the government and other consumers rather than themselves. A possible explanation is that millennials' altruistic actions are driven from their genuine concern for the wellbeing of others, as empathy-altruism hypothesis suggests (Batson 1991), while their engagement in green behaviors mainly stem from self-directed motives. In other words, millennials do not seem to perceive pro-environmental behaviors as pro-social actions that directly improve the well-being of others. It appears millennials tend to "go green" only when the benefits to themselves outweigh the costs, thus creating a disconnect between their selfless altruistic actions and their green consumption behaviors. Another plausible explanation for these findings could be the way altruism was measured in this study (SRAS scale). While this scale has been widely used in social psychology research to measure an individual's inherent tendencies to help others, it is not the most commonly used scale to measure altruism in connection with green behavior. For instance, the 9-item scale used by Clark et al. (2003) was constructed based on the Schwartz' (1977) normactivation model to measure altruistic attitudes. However, a closer look at the scale items reveals that the scale actually measures general attitudes and beliefs with regard to altruism and social responsibility rather than the individual's inherent tendency to engage in altruistic actions. In addition, 3 items directly measure pro-environmental attitudes and beliefs, which may have caused the correlation between altruism and green behavior ("I worry about conserving energy only when it helps to lower my utility bills", "Households like mine should not be blamed for environmental 
problems caused by energy production and use" and "Use of renewable energy is the best way to combat global warming").

Based on these results, it may be concluded that rational and self-oriented motives are more important in predicting college age millennials' commitment to act environmentally friendly. This conclusion is in line with previous research showing that self-oriented motives such as concern for self-image, status seeking, and need for admiration, significantly motivate pro-environmental actions in young consumers (Griskevicius et al. 2010; Lee 2008; Naderi and Strutton 2014, 2015). Indeed, there exists a strong belief that "environmental change will happen only when it is in people's self-interest" (Twenge and Campbell 2009, p. 268).

\section{Practical Implications}

The findings of this study have implications for environmental advocates, policy makers, and green marketers. As consumers look for tangible green benefits, economic rationality is still a significant player in this field, particularly for millennials who not only have limited financial resources, but also experienced one of the worst global economic recessions in 2008. The recent recession has changed consumer criteria for eco-friendly products. While some consumers may be willing to pay more for green products, millennials' financial constraints could pose a challenge. Therefore, green brands will have to reconcile this changing mindset with products that have historically commanded a price premium. Additionally, environmental regulators and law makers should continue their efforts to provide economic incentives such as tax cuts and zero-interest loans to encourage pro-environmental purchases among this cohort.

Further, because frugality was shown to influence millennials' behavior related to green products, marketers must demonstrate the value of the product or brand in order to win millennials' favor. In general, products that are environmentally friendly are considered to be more expensive 
(Chen and Chai 2010; Muralidharan and Xue 2016) but lower quality. Thus, millennials who consider their financial capabilities when making pro-environmental purchases must be made aware of the complete value of the product. However, as previously mentioned, the value cannot be an environmental one alone. Playing to millennials' frugality, marketers must communicate cost savings to millennial shoppers over time. For example, marketing for an LED light bulb or a water usage reducing showerhead must include messages communicating savings on the monthly electric or water bill. In this way, millennials will understand the financial benefits to themselves, thus touching on the findings that frugality does motivate millennial pro-environmental consumption behavior.

Altruism in this research was not a significant predictor of green behavior among millennials, which contradicts the findings of previous studies in this domain for general samples (Clark, Kotchen, and Moore 2003; de Groot and Steg 2009). Therefore, using only “otheroriented" marketing messages in this context may not be the most effective way to promote green products among millennials. In other words, messages with an emphasis on the importance of improving the environment for the well-being of society may not strongly influence millennials' green behavior. This, however, does not also imply that green marketers should unquestionably pursue "self-directed" targeting strategies to attract this generation of consumers.

Moreover, because Western culture is dominantly future-oriented (Karniol and Ross 1996), an emphasis on future outcomes of acting environmentally friendly could be an effective strategy for promoting green consumption. Future-oriented millennials tend to set goals and make lists of things to do, resist temptations when there is work to be done, and consider specific means for reaching their goals. A natural implication for green marketers and policy makers is to clearly communicate how taking small steps today leads to significant outcomes tomorrow. For instance, 
how much money they can save in long term (e.g., next 5 or 10 years) by switching to highefficiency LED lamps or how driving electric vehicles could have long term societal and economic impact in their country (e.g., on GDP or air quality). Finally, using risk attached to acting irresponsibly toward the environment as the main appeal of the promotional message may not be an effective strategy in persuading this generation to behave greenly unless the direct link between the promoted product and its ecological consequences is shown and emphasized clearly.

\section{Limitations and Future Research}

This study provides some new insights into the factors that may encourage or hinder proenvironmental behaviors among millennials. However, as with any study, this research is subject to certain limitations. First, a convenience sample of college students was used in this study and the only screening factor to qualify them as millennials was their age. Therefore, the findings are not generalizable to the entire millennial population. While millennials as a generation are often identified according to their age or life-state (Gurău 2012), other factors such as lifestyle and interests may also be used to better define this group of consumers. Future research should further explore these factors using more representative samples. Second, empirical support was not found for the hypothesized effects of altruism and risk aversion on green behavior; it would be interesting to see if these findings could be replicated using other scales to measure altruism and risk aversion. Third, green behavior is normally regarded as "socially desirable." While self-administered questionnaires were used for data collection and every effort was made to ensure anonymity and confidentiality of responses, social desirability bias could influence the way participants reported their green behaviors. Finally, this work was a cross-sectional study and thus could not provide a causal inference. Therefore, future experimental studies are required to examine whether priming 
or manipulating altruism, frugality, future-orientation, and risk attitudes encourage millennials engage in green behavior more often.

\section{Concluding Remarks}

Millennials grasp the environmental consequences of their actions and have the education, motivation, and social awareness to participate in the green movement. However, they have not truly begun to fully integrate their beliefs and actions. In fact, millennial consumers could show comparable behaviors for entirely different reasons. For instance, one may buy and drive a hybrid car to save money on gasoline while the other may drive an electric car to showcase his/her interest in environmental conservation in the hope of enhancing his/her social status. As eco-friendly product claims become more tangible to consumers, brands have an opportunity to grow green portfolios by segmenting their customers who seek green products for different reasons, such as health, sustainability, and cost. The present study was an initial attempt to address this issue and future research should examine other motivations for green consumption among this specific generation of young consumers.

\section{References}

Anvar M, Venter M (2014) Attitudes and purchase behavior of green products among generation Y consumers in South Africa. Mediterranean Journal of Social Sciences, 5:183-194.

Aruna S, Santhi P (2015) Impulse purchase behavior among generation-Y. IUP Journal of Marketing Management, 14:21-38.

Bamberg S (2003) How does environmental concern influence specific environmentally related behaviors? A new answer to an old question. Journal of Environmental Psychology, $23: 21-32$ 
Batson CD (1991) The altruism question: Toward a social-psychological answer. Erlbaum, Hillsdale, NJ

Bekin C, Carrigan M, Szmigin I (2007) Beyond recycling: 'Commons-friendly' waste reduction at new consumption communities. Journal of Consumer Behaviour, 6:271-286

Brown D, Hayes N (2008). Influencer marketing: Who really influences your customers? Butterworth-Heinemann, Burlington, MA.

Burton S, Lichtenstein DR, Netemeyer RG, Garretson JA (1998) A scale for measuring attitude toward private label products and an examination of its psychological and behavioral correlations. Journal of the Academy of Marketing Science, 26:293-306

Casaló LV, Escario JJ (2016) Intergenerational association of environmental concern: Evidence of parents' and children's concern, Journal of Environmental Psychology, 48:65-74

Casimir G, Dutilh C (2003) Sustainability: A gender studies perspective. International Journal of Consumer Studies, 27:316-325

Chan RYK (2001) Determinants of Chinese consumers' green purchase behavior. Psychology \& Marketing, 18:389-413

Chen TB, Chai LT (2010) Attitude towards the environment and green products: consumers' perspective. Management Science and Engineering, 24:27-39.

Clark CF, Kotchen MJ, Moore MR (2003) Internal and external influences on pro-environmental behavior: Participation in a green electricity program. Journal of Environtal Psychology, $23: 237-246$

Cramer P (2011) Young adult narcissism: A 20 year longitudinal study of the contribution of parenting styles, preschool precursors of narcissism, and denial. Journal of Research in Personality, 45:19-28 
D’Souza C, Taghian M, Lamb P, Peretiatko R. (2007) Green decisions: Demographics and consumer understanding of environmental labels. International Journal of Consumer Studies, 31:371-376

de Groot JIM, Steg L (2009) Mean or green: Which values can promote stable proenvironmental behavior? Conservation Letters, 2:61-66

DeYoung R (1986) Encouraging Environmentally appropriate behavior: The role of intrinsic motivation. Journal of Environmental Systems, 15:281-291

Diamantopoulos A, Schlegelmilch BB, Sinkovics RR, Bohlen GM (2003) Can sociodemographics still play a role in profiling green consumers? A review of the evidence and an empirical investigation, Journal of Business Research, 56:465-480

Fischer D, Böhme T, Geiger SM (2017) Measuring young consumers' sustainable consumption behavior: Development and validation of the YCSCB scale. Young Consumers, 18:312326

Fornell C, Larcker DG (1981) Evaluating structural equation models with unobservable variables and measurement error. Journal of Marketing Research, 18:39-50

Frame B, Newton B (2007) Promoting sustainability through social marketing: Examples from New Zealand. International Journal of Consumer Studies, 31:571-581

Franzen A (2003) Environmental attitudes in international comparison: An analysis of the ISSP surveys 1993 and 2000. Social Science Quarterly, 8:297-308.

Gurău C (2012) A life-stage analysis of consumer loyalty profile: comparing generation X and millennial consumers. Journal of Consumer Marketing, 29:103-113.

Geller ES (1995) Actively caring for the environment: An integration of behaviorism and humanism. Environment \& Behavavior, 27:184-195 
Griskevicius V, Tybur JM, Van den Bergh B (2010) Going green to be seen: Status, reputation, and conspicuous conservation. Journal of Personality \& Social Psychology, 98:392-404

Grønhøj A, Thøgersen J (2009) Like father, like son? Intergenerational transmission of values, attitudes, and behaviours in the environmental domain. Journal of Evnironmental Psychology, 29:414-421.

Head LA (2013) Millennials are greener! Really? Shelton Group. Accessed January 17, 2016

Henry, L (2017) Are young people becoming more risk averse? An analysis of factors contributing to the rise of precautionary savings among young adults. Business Economics, 52:32-40.

Horton RS, Tritch T (2014) Clarifying the links between grandiose narcissism and parenting. Journal of Psychology, 148: 133-143

Horton RS, Bleau G, Drwecki B (2006) Parenting narcissus: What are the links between parenting and narcissism?. Journal of Personality, 74:345-376

Jain SK, Kaur G (2004) Green marketing: An attitudinal and behavioral analysis of Indian consumers. Global Business Review, 5:187-205

Jain SK, Kaur G (2006) Role of socio-demographics in segmenting and profiling green consumers: An exploratory study of consumers in India. Journal of Internation Consumer Marketing, 18:107-117

Jang YJ, Kim WG, Bonn, MA (2011) Generation Y consumers' selection attributes and behavioral intentions concerning green restaurants. International Journal of Hospitality Management, 30:803-811. 
Johnson CY, Bowker JM, Cordell HK (2004) Ethnic variation in environmental belief and behavior: An examination of the new ecological paradigm in a social psychological context. Environment and Behavior, 36:157-186.

Kanchanapibul M, Lacka E, Wang X, Chan HK (2014) An empirical investigation of green purchase behaviour among the young generation. Journal of Cleaner Production, 66:528536.

Karniol R, Ross M (1996) The motivational impact of temporal focus: Thinking about the future and the past. Annual Review of Psychology, 47:593-620

Kilbourne WE, Beckmann SC (1998) Review and critical assessment of research on marketing and the environment. Journal of Mareting Management, 14:513-532

Kollmuss A, Agyeman J (2002) Mind the gap: Why do people act environmentally and what are the barriers to pro-environmental behavior? Environmental Education Research, 8:239260

Lappänen JM, Haahla AE, Lensu AM, Kuitunen MT (2012) Parent-child similarity in environmental attitudes: a pairwise comparison. The Journal of Environmental Education, 42:162-176.

Laroche M, Bergeron J, Barbaro-Forleo G (2001) Targeting consumers who are willing to pay more for environmentally friendly products. Journal of Consumer Marketing, 18:503-520

Larson LRL, Eastman JK, Bock DE (2016) A multi-method exploration of the relationship between knowledge and risk: The impact on millennials' retirement investment decisions. Journal of Marketing Theory and Practice, 24:72-90

Lastovicka JL, Bettencourt LA, Shaw Hughner R, Kuntze RJ (1999) Lifestyle of the tight and frugal: Theory and measurement. Journal of Consumer Research, 26:85-98 
Lee JD, Bahl A, Black GS, Duber-Smith DC, Vowles NS (2016) Sustainable and nonsustainable consumer behavior in young adults. Young Consumers, 17:78-93

Lee K (2008) Opportunities for green marketing: Young consumers. Marketing Intelligence \& Planning, 26:573-586

Li LY (1997) Effect of collectivist orientation and ecological attitude on actual environmental commitment: The moderating role of consumer demographics and product involvement. Journal of International Consumer Marketing, 9:31-53

Mainieri T, Barnett EG, Valdero TR, Unipan JB, Oskamp S (1997) Green buying: The influence of environmental concern on consumer behavior. Journal of Social Psychology, 137:189204.

Mangold WG, Smith KT (2014) Selling to millennials with online reviews. Business Horizons, $55: 141-153$.

McCabe K, Barnett D (2000) First comes work, then comes marriage: Future orientation among African American young adolescents. Family Relations, 49:63-70

McKenzie-Mohr D (2000) Promoting sustainable behavior: An introduction to community-based social marketing. Journal of Social Issues, 56:543-554

Meeusen C (2014) Concern: the influence of parents and communication patterns within the family. The Journal of Environmental Education, 45:77-90.

Meijinders AL, Midden CJH, Wilke HAM (2001) Communications about environmental risks and risk-reducing behavior: The impact of fear on information processing. Journal of Applied Social Psychology, 31:754-777

Moisander J (2007) Motivational complexity of green consumerism. International Journal of Consumer Studies, 30:404-409 
Muralidharan S, Xue F (2016) Personal networks as a precursor to a green future: A study of "green" consumer socialization among young millennials from India and China. Young Consumers, 17:226-242

Naderi I, Strutton D (2014) Can normal narcissism be managed to promote green product purchases? Investigating a counterintuitive proposition. Journal of Applied Social Psychology, 44:375-391

Naderi I, Strutton D (2015) I support sustainability but only when doing so reflects fabulously on me: Can green narcissists be cultivated? Journal of Macromarketing, 35:70-83

Newman GE, Gorlin M, Dhar R (2014) When going green backfires: How firm intentions shape the evaluation of socially beneficial product enhancements. Journal of Consumer Research, 41: 823-839

Nielsen (2015) The sustainability imperative. Accessed January 18, 2016

Norum PS (2008) The role of time preference and credit card usage in compulsive buying behavior. International Journal of Consumer Studies, 32: 269-275

Olli E, Grendstad D, Wollebark D (2001) Correlates of environmental behaviors: Bringing back social context. Environment \& Behavior, 33:181-208

Ottman JA, Stafford ER, Hartman CL (2006) Avoiding green marketing myopia: Ways to improve consumer appeal for environmentally preferable products. Environment, 48, 2236

Otto S, Kaiser FG (2014) Ecological behavior across the lifespan: Why environmentalism increases as people grow older. Journal of Environmental Psychology, 40:331-338 Peattie K (2001) Golden goose or wild goose? The hunt for the green consumer. Business Strategy \& Environment, 10:187-199 
Peattie K (2010) Green consumption: Behavior and norms. Annual Review of Environment and Resources, 35:195-228

Pew Research Center (2011) The generation gap and the 2012 election: Domestic and foreign policy views. Accessed Januray 19, 2016

Pritchard ME, Myers BK, Barbara, Cassidy DJ (1989) Factors associated with adolescent saving and spending patterns. Adolescence, 24:711-723

Reisenwitz TH, Iyer R (2009) Differences in generation X and generation Y: implications for the organization and marketers. Marketing Management Journal, 19:91-103.

Roberts JA (1996) Green consumers in the 1990s: Profile and implications for advertising. Journal of Business Research, 36:217-231

Roberts JA, Bacon DR (1997) Exploring the subtle relationships between environmental concern and ccologically conscious consumer behavior. Journal of Business Research, 40:79-89

Rosenburg J (2015) Millennials green up American consumerism. Accessed January 19, 2016

Rushton JP, Chrisjohn RD, Fekken GC (1981) The altruistic personality and the self-report altruism scale. Personality \& Individual Difference, 2:293-302

Rutter M, Robin M, Pickles A (2001) Testing hypotheses on specific environmental causal effects on behavior. Psychological Bulletin, 127:291

Sago B (2010) The influence of social media message sources on millennial generation consumers. International Journal of Integrated Marketing Communications, 2:7-18.

Schaefer A, Crane A (2005) Addressing sustainability and consumption. Journal of Macromarketing, 25:76-92

Schawbel D (2015) 10 new findings about the millennial consumer. Accessed January 11, 2016 
Schwartz S (1977) Normative influences on altruism. Advances in Experimental Social Psychology, 10:222-279

Schwepker CHJ, Cornwell TB (1991) An examination of ecologically concerned consumers and their intention to purchase ecologically packaged products. Journal of Public Policy \& Marketing, 10:77-101

Seguin C, Pelletier LG, Hunsley J (1999) Predicting environmental behaviors: The influence of self-determined motivation and information about perceived environmental health risks. Journal of Applied Social Psychology, 29:1582-1604

Seitz MA, Peattie K (2004) Meeting the closed-loop challenge: The case of remanufacturing. Californial Management Review, 46:74-89

Shrum LJ, McCarty JA, Lowrey TM (1995) Buyer characteristics of the green consumer and their implications for advertising strategy. Journal of Advertising, 24:71-82

Steinberg L, Sandra G, o’Brien L, Woolard J, Cauffman E, Banich M, Marie (2009) Age differences in future orientation and delay discounting. Child Development, 80:28-44

Stern PC (1976) Effect of incentives and education on resource conservation decisions in a simulated common dilemma. Journal of Personality \& Social Psychology, 34:1285-1292

Stern PC, Dietz T, Abel T, Guagnano GA, Kalof L (1999) A value-belief-norm theory of support for social movements: The case of environmentalism. Human Ecology Review, 6:81-97

Strathman A, Gleicher F, Boninger DS, Edwards CS (1994) The consideration of future consequences: weighing immediate and distant outcomes of behavior. Journal of Personality \& Social Psychology, 66:742-752

Straughan RD and Roberts JA (1999). Environmental segmentation alternatives: A look at green consumer behavior in the new millennium. Journal of Consumer Marketing, 16:558-575. 
Twenge JM (2006) Generation me: Why today's young Americans are more confident, assertive, entitled, and more miserable than ever before. Free Press, New York, NY

Twenge JM, Campbell WK (2009) The narcissism epidemic: Living in the age of entitlement. Free Press, New York, NY

Twenge JM, Foster JD (2010) Birth cohort increases in narcissistic personality traits among American college students, 1982-2009. Social Psychological \& Personality Science, 1:99-106

U.S. Census Bureau (2015) Millennials outnumber Baby Boomers and are far more diverse. Accessed 15 January 2016

Uyeki E, Holland L (2000) Diffusion of pro-environmental attitudes?. American Behavioral Scientist, 43:646-662.

Webster JD, Ma X (2013) A balanced time perspective in adulthood: Well-being and developmental effects. Canadian Journal on Aging, 32:433-442

Winograd M, Hais M (2014) How Millennials could upend Wall Street and Corporate America. Accessed January 17, 2016

Wray-Lake L, Flanagan CA, Osgood DW (2010). Examining trends in adolescent environmental attitudes, beliefs, and behaviors across three decades. Environment and Behavior, 42:6185.

Zimbardo PG, Boyd JN (1999) Putting time in perspective: A valid, reliable individualdifferences metric. Journal of Personality \& Social Psychology, 77:1271-1288 
Table 1 Convergent and Discriminant Validity Assessment Using CFA

\begin{tabular}{lcccccc}
\hline \hline & CR & Altruism & Frugality & Futurism & Risk & Green \\
\hline Altruism & .820 & .436 & & & & \\
Frugality & .844 & .096 & .449 & & & \\
Futurism & .848 & .221 & .250 & .449 & & \\
Risk Averseness & .676 & .000 & .102 & .068 & .348 & \\
Green Behavior & .926 & .012 & .144 & .144 & .006 & .533 \\
\hline \hline
\end{tabular}

The lower diagonal elements are phi-squares $\left(\Phi^{2}\right)$ and the diagonal elements (highlighted) are the AVEs.

Table 2 Structural Equation Modeling Results

\begin{tabular}{lccl}
\hline \hline Structural Links & Coefficient & $t$-value & \\
\hline H1: Altruism $\rightarrow$ Green Behavior & -0.08 & -1.00 & Not Supported \\
H2: Frugality $\rightarrow$ Green Behavior & 0.34 & $4.11^{* *}$ & Supported \\
H3: Futurism $\rightarrow$ Green Behavior & 0.18 & $2.07^{*}$ & Supported \\
H4: Risk Averseness $\rightarrow$ Green & -0.07 & -0.95 & Not Supported
\end{tabular}

Diagnostic Statistics

Chi-square $\left(\chi^{2}\right)$

Degrees of freedom $(d f)$

$\chi^{2} / d f$

RMSEA

SRMR

IFI

CFI

NFI

NNFI

GFI

AGFI
1049.40

550

1.91

0.057

0.063

0.95

0.95

0.91

0.95

0.82

0.79

* Statistical significance at the .05 level

** Statistical significance at the .001 level 
Figure 1 Proposed Model Tested in the Study

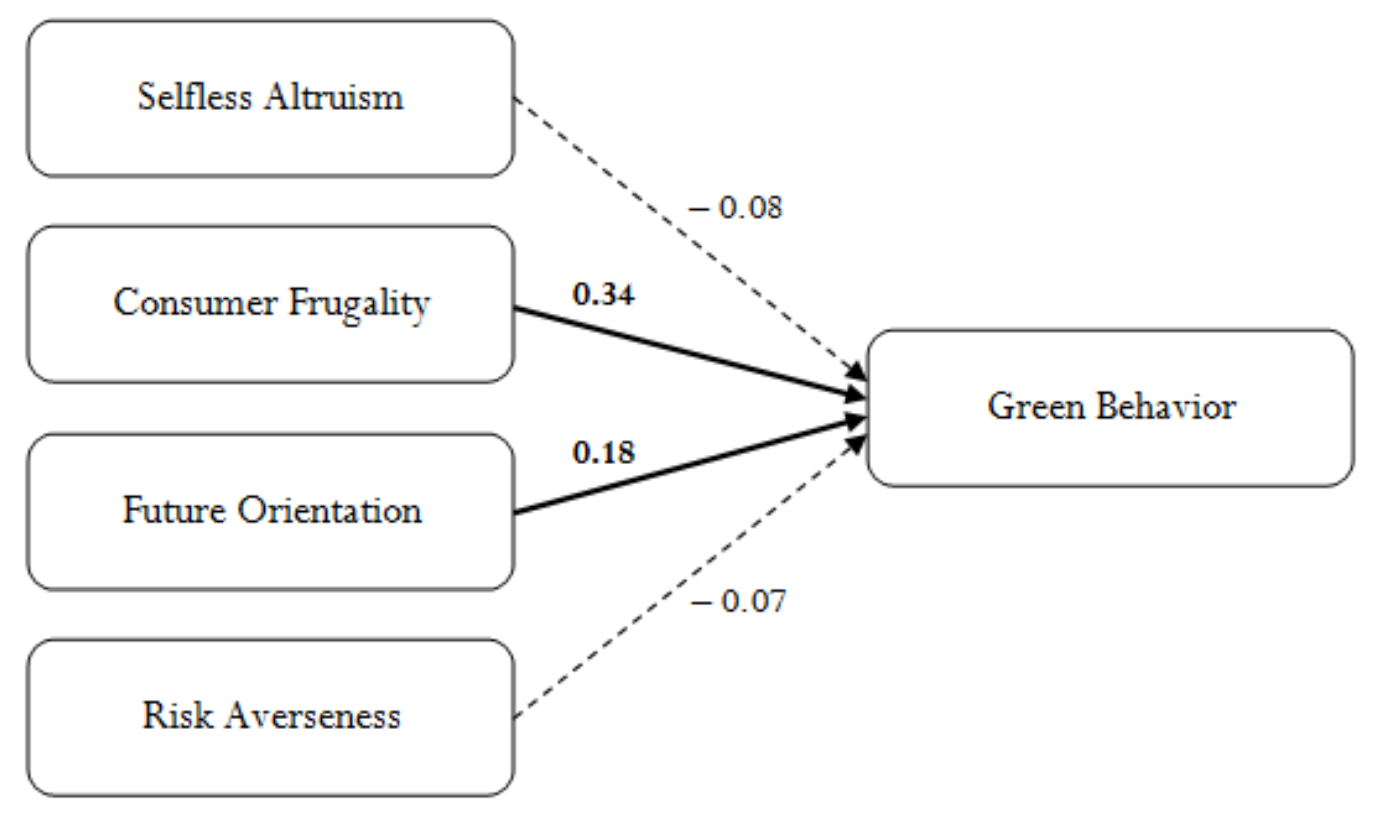




\section{APPENDIX A}

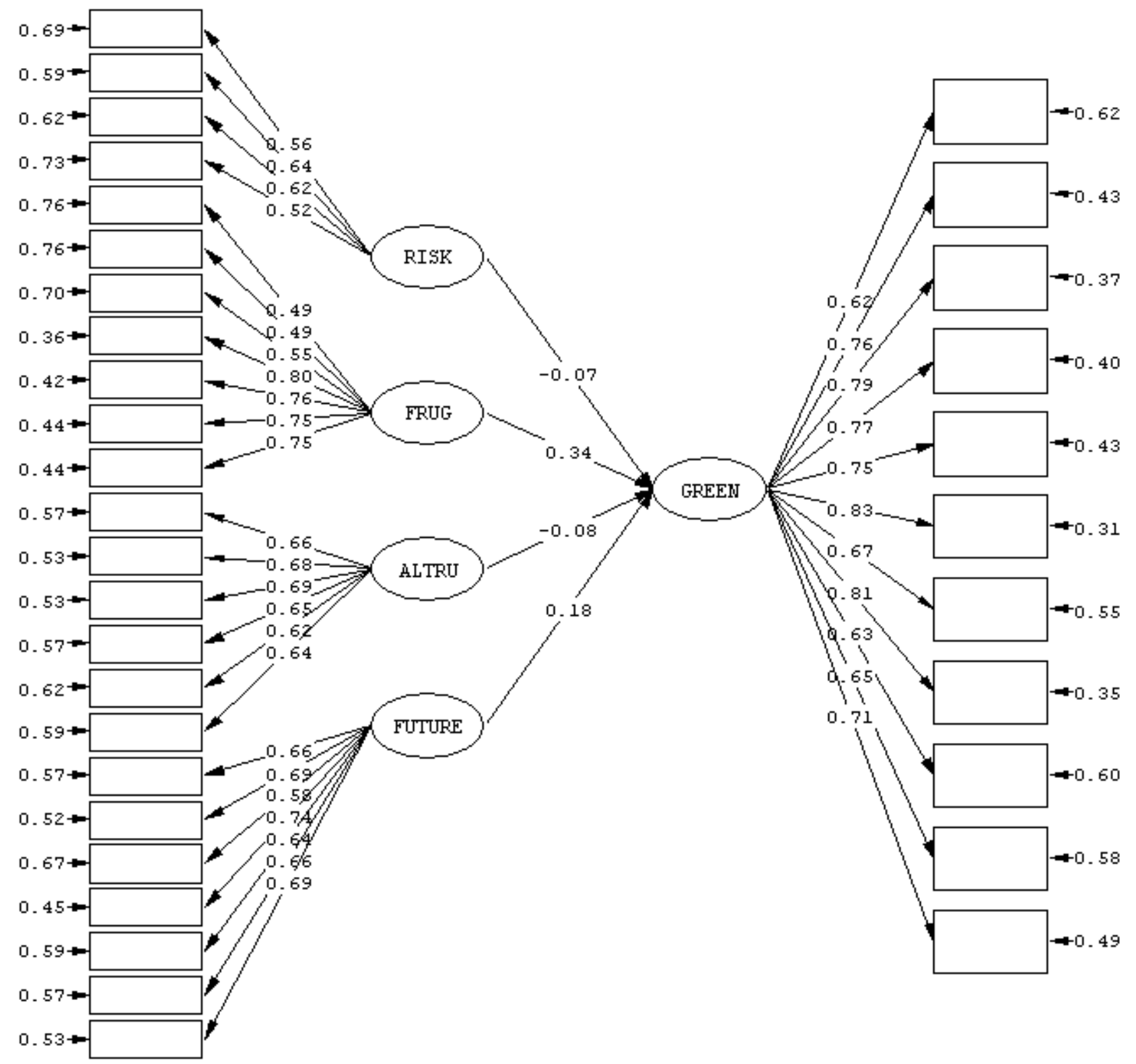

